\title{
CAUSES AND CONSEQUENCES OF TURKEY'S OUT-OF-WAR POSITION IN THE IRAQ WAR \\ OF 2003
}

\author{
RAMAZAN GÖZEN
}

\begin{abstract}
This article examines Turkey's 'position' in the Iraq war of 2003 by focusing on a very important decision made by the Turkish Grand National Assembly on 1 March 2003. It argues that the decision was a product of several factors and pressures, producing both positive and negative consequences for Turkey. Its most important positive consequence is that the TGNA showed its influence over Turkish foreign policy making for the first time since the 1970s. However, it also generated some strategic changes regarding Turkey's relations with the US and the EU. While Turkish-US relations experienced a 'crisis of confidence', Turkish-EU relations recorded a rapprochement since 2003.
\end{abstract}

\section{KEYWORDS}

US-Turkish relations, Turkish foreign policy, Iraq war, parliament and foreign policy, northern Iraq 
To the surprise of observers, both in Turkey and abroad, Turkey opted to remain out of the Iraq war. On 1 March 2003, the Turkish Grand National Assembly (TGNA) refused to back a mandate that would have allowed the deployment of 62,000 US soldiers in Turkey in order to open a second front in northern Iraq, and the dispatching of a similar number of Turkish soldiers into Iraq for preventing potential security risks which could emerge during the war. Their refusal was unexpected, given the pattern of Turkish foreign policy towards the Iraq problem and the history of Turkey's relations with the US.

By refusing the government's motion, the TGNA not only prevented Turkey from giving support to US policy, but also barred her involvement in the war. Rejecting full cooperation with a longtime ally, the US, also represented a significant shift in the Turkish foreign policy, with serious implications not only for TurkishAmerican relations, but also for the Turkish foreign policy towards Iraq and the European Union. This article will attempt to examine the causes and consequences of Turkey's out-of-war position for Turkey and the Turkish foreign policy by focusing on the TGNA's decision. Before answering these questions, Turkey's delicate position vis-à-vis the Iraq war will be analyzed.

\section{A Delicate Positioning}

Turkey's position towards the Iraq war was, in a sense, 'delicately critical' simply because of its geo-strategic, geo-political and geo-economic location as Iraq's neighbor on the one hand and as the US's close ally on the other. Turkey was thus squeezed between two interests, i.e. keeping its security, economic and political interests vis-à-vis Iraq and maintaining its alliance with the US, which were not necessarily complementary.

Turkey has always been concerned about security and socioeconomic consequences of any instability in Iraq due to the fact that Turkey and Iraq are more than ordinary neighbors. Their relationship 
can be defined as 'complex interdependence', ${ }^{1}$ based on a set of mutual economic, historical, socio-cultural and security connections. From the 1920s right up until the Gulf War of 1990-1991, the two countries had close cooperation in economic and security matters. In particular, during the 1980s, Iraq was one of Turkey's best economic partners, thanks to the twin oil pipelines between the two countries and certain advantages generated by the Iran-Iraq war. Similarly, Turkey and Iraq cooperated in fighting against terrorist and separatist groups sheltering in each other's territory; including the signing of the Turkish-Iraqi Agreement of 1978, which enabled them to conduct 'hot pursuit' operations to fight against such groups. ${ }^{2}$

Interdependent relations were cut off during the Gulf War, however, and since then overall relations have greatly deteriorated. Due to the suspension of interdependent relations, the aforementioned benefits were disrupted, causing high costs for both countries in economic, political and security fields. Moreover, Turkey's concerns about Iraq did not end. During the 1990s, Turkey struggled to eliminate the negative effects of power vacuum in northern Iraq, such as terrorism and the establishment of a Kurdish state, and to keep the oil pipelines opened under the UN Security Council resolutions. To achieve all these objectives, Turkey maintained a close cooperation with the US, the most illustrative example of which was the deployment of the Poised Hammer forces at the İncirlik base, established in south eastern Turkey after the end of the Gulf War.

The second dimension of Turkey's delicate position in the Iraq War was of course its relationship with the US, which operates not only at bilateral levels, but also at multilateral ones, within the context of NATO and international financial institutions, like the IMF. Since the early years of the Cold War, Turkey and the US have had close cooperation on many issues in the region and the world. The most recent and the most important example of this was recorded in the Gulf War and the aftermath of the war during the 1990s.

\footnotetext{
${ }^{1}$ The concept is borrowed from Robert O. Keohane and Joseph S. Nye, Power and Interdependence: World Politics in Transition (Boston, MA: Little Brown, 1977).

${ }^{2}$ For more about Turkish-Iraqi complex interdependence see Ramazan Gözen, 'Turkish-Iraqi Relations: From Cooperation to Uncertainty,' Foreign Policy(Ankara), Vol. 29, Nos. 3-4 (1995), pp. 49-98.
} 
During this period, the two countries shared a strategic consensus on most of the developments concerning the reconstruction of the postCold War system in the Balkans, the Caucasus, Central Asia, Europe, and the Middle East--including the Iraqi problem.

Based on the record of the preceding decade, one would have expected Turkey to cooperate with the US in this case--not only to continue its good relations with the US, but also to maintain its interests and influence over Iraq. Indeed, this was what Turkey had done during the 1990s when, under the leadership of President Turgut Özal, it had cooperated with the US by imposing sanctions on Iraq, and opening Turkish air bases for the use of US warplanes.

As early as January 2003, the administration of George W. Bush asked the Turkish government to allow the use of six airbases and airports and three Mediterranean ports, to open Turkish territory for the passage of some 80,000 US troops to Iraq, and also to allow the deployment of 6,000 US Special Forces in Turkey, for five years. ${ }^{3}$ Unsurprisingly at that stage, the Turkish government, led by Abdullah Gül, was placed in a dilemma between backing the US operation and attempting to resolve the crisis by peaceful means. Initial analyses of the government's positioning seemed to agree that it was eager 'not be seen as anxious to back the US attack'. ${ }^{4}$ Accordingly, Prime Minister Gül toured six regional countries, and hosted a summit of these six nations in İstanbul, to show both the world and the Turkish public that Turkey was in favor of a peaceful resolution of the crisis. However, once becoming convinced of the US's determination to launch the military operation, the government changed its mind and expressed its willingness to cooperate with the US in the Iraq war, on the condition that there would be US guarantees to Turkey in the economic, security/military and political fields. In other words, to

\footnotetext{
3In December 2002 US Assistant Secretary of Defence Paul Wolfowitz asked in Ankara 'a high level involvement by Turkey' in US operation in Iraq. Nicole Pope, 'Turkey is Playing Hard to Get,' Middle East International, No. 691, 10 January 2003, pp. 14-15.

${ }^{4}$ Gareth Jenkins, 'Muslim Democrats in Turkey?', Survival, Vol. 45, No. 1 (Spring 2003), pp. 45-66.
} 
prevent possible negative impacts of the war, the Turkish government asked the Americans to commit to a kind of guarantee agreement. ${ }^{5}$

While still negotiating with the US, the Turkish government presented the motion to the TGNA, which would authorize the government to allow passage of US troops through Turkey and to dispatch Turkish troops into Iraq. Very surprisingly, in its session on 1 March 2003, the TGNA decided not to endorse the government motion stipulating US-Turkish military cooperation in the Iraq war. The government's policy towards the war was thus disrupted and blocked. Why did the TGNA refuse the government motion?

\section{Causes of Turkey's Out-of-War Position}

\section{Illegitimacy of the US Operation}

The TGNA decision was made under the influence of several factors, the first of which was the illegitimacy of the US operation. To begin with, an overwhelming majority of the Turkish people, including the decision-makers, saw the US war against Iraq as an illegitimate action. From the beginning to the end of the pre-war period, Turkey's top decision-makers ${ }^{6}$ and decision-making organs ${ }^{7}$ linked Turkey's participation in the US-led war to the existence of international legitimacy. In their opinion, to comply with the international legitimacy condition of Article 92 of the Turkish Constitution, there needed to be a UN Security Council resolution to allow the US to conduct any operation.

After the Summit meeting on 17 January 2003 at the Presidential Palace, in which several high level decision makers (President Sezer, Prime Minster Gül, Foreign Minister Yakış, Defence Minister Gönül and Chief of Staff Özkök) participated, it

${ }^{5}$ For instance, Briefing, No. 1429, 27 January 2003.

${ }^{6}$ Necdet Sezer (President), Bülent Arınç (Speaker of the TGNA), Abdullah Gül (former Prime Minister), and Recep Tayyip Erdoğan (Leader of the $\mathrm{AKP}$ and Prime Minister).

${ }^{7}$ The National Security Council, the Council of Ministers, Special Summit Meeting on Iraq. 
was stated that '...without a second UN Security Council decision [after Resolution 1441], it would be difficult to obtain a mandate from the Parliament.... ${ }^{8}$ Later, on 31 January, the National Security Council recommended to the government that "peaceful means continue to be sought...in accordance with Article 92 of the Constitution...conditional to the international legitimacy'. ${ }^{9}$ The President himself made a similar statement just before the TGNA's related session, that 'international legitimacy is required for the TGNA to make a decision.' 10

\section{The Pressure of Public Opinion}

Similar views were prevalent among the majority of the public, who regarded the US operation against Iraq as unlawful, immoral and unprincipled. The US administration was criticized for pursuing a selfish and imperialist policy towards Iraq in particular and the Islamic world in general.

The public was also concerned about any US grand-design policy to re-shape the region not only by changing political regimes (beginning with Afghanistan and Iraq, but apparently moving on to Iran, Syria, Saudi Arabia and so on), but also by re-drawing political borders, both of which would have negative implications for Turkey as well as for other regional countries.

Another important theme which was widely shared by the public during the US-Turkey negotiation process was that the American use of Turkish territories and the deployment of US troops in Turkey was similar to the presence of occupying British-French troops in Turkey after the First World War. Thus, to avoid such an appearance, Turkey had to refuse the US request.

Although there were some different interpretations of the Turkish Constitution by some Turkish academics, columnists and politicians, the overwhelming majority of the opinion makers were in

\footnotetext{
${ }^{8}$ Briefing, No. 1428, 20 January 2003.

${ }^{9}$ Ayın Tarihi, 1 February 2003; Briefing, No. 1431, 10 February 2003.

${ }^{10}$ Briefing, No. 1433, 3 March 2003.
} 
consensus on the need for the adoption of a UN Security Council resolution to ensure the international legitimacy of the US attack on Iraq.

Thus, by the eve of the war, public surveys revealed that about 94 percent of the Turkish people were against the US operation. In particular, public opinion makers in the media, a number of both right and left-wing civil society groups, and academics appearing in the media, showed an unequivocal opposition to the Iraq war.

Among these groups, the Islamist public opinion makers played a decisive role. Pro-Islamist television channels in Turkey, such as Kanal 7 or STV, and pro-Islamist Turkish newspapers such as Yeni Safak, Vakit and Zaman, all enjoying some degree of influence on the government of the AKP (Justice and Development Party), were very outspoken against the war, and against Turkey's involvement in the war on the side of the US. Some popular and influential Islamist columnists, writers, academics and intellectuals influenced not only the views of the-man-in-the-street, but also of AKP parliamentarians, most of whom have Islamic backgrounds and sensitivities, and who received votes from Islamic voters in the last elections.

Given the fact that most of the AKP parliamentarians are sympathetic to and respectful of the Islamic public opinion, when casting their votes, they ultimately chose to listen to the voice of the public opinion, not to that of the government leadership. On the evening before the voting in the TGNA, the parliamentarians were sent 'vote no!' messages to their e-mail addresses, mobile telephones, and to their offices in the parliament. ${ }^{11}$ There were also allegations that in particular those parliamentarians having connections in some way with Necmettin Erbakan, the leader of the pro-Islamic party movement in Turkey, voted under the influence of Erbakan and other Islamic leaders in Turkey, who were against the US operation. ${ }^{12}$

\footnotetext{
${ }^{11}$ Interview with some AKP parliamentarians. Names are not permitted to disclose.

${ }^{12}$ However, none of the interviewed accepted such allegations.
} 


\section{Legacy of the Gulf War of 1990-91}

One of the most important reasons behind the opposition of the Turkish public and decision makers was the legacy of the Gulf War. ${ }^{13}$ Be they parliamentarians, the public, or the state bureaucracy, an overwhelming majority of Turkish people believes that the previous Gulf War cost Turkey a lot in a number of areas. Turkey was very disappointed with that war's consequences. Turkey's losses can be categorized into three groups: economic losses, security problems, and political difficulties.

Economically speaking, it is estimated that Turkey's total losses as a result of the Gulf War amounted to about $\$ 40$ billion. Turkey received as compensation not more than 20 percent of its economic losses, a fact that played an important role in the emergence of an economic crisis in Turkey in the late 1990s.

In security terms, Turkey faced growing terrorist attacks as a result of a power vacuum in northern Iraq, created by the imposition of no-fly zone and the exclusion of the Iraqi central authority from northern Iraq. Indeed, Turkey was unable to control the region despite the presence of the Poised Hammer forces at the İncirlik base, and despite occasional military interventions into the region to combat the terrorists encamped there. In response to the Kurdish insurgency within its own borders and the neighboring power vacuum which offered the terrorists shelter in the 1990s, Turkey's foreign and domestic policies became security-intensive. Turkey's economic, human and time resources were galvanized into security-oriented policies, causing great damage to Turkey's development and modernization. Moreover, the possibility of the establishment of a Kurdish state was increased as the Kurds in the north of Iraq had more freedom of political, military and economic organization.

Politically speaking, mainly because of this overloaded security agenda in Turkish politics, political freedoms, economic motivations and human rights were curbed down. Turkey was nearly isolated from

\footnotetext{
${ }^{13}$ Solmaz Ünaydın, 'Turkey's Policy Towards the Middle East and the Question of Iraq,' Turkish Policy Quarterly, Vol. 1, No. 4 (Winter 2002), pp. 31-40.
} 
global political and economic developments. It faced difficulties in its relations with the EU, and occasionally with the US, due to the security-oriented policies that were spawned by its war against the PKK. Moreover, Turkey's relations with the Middle East and the Islamic world were clouded by the same approach.

In addition to these bitter memories, and perhaps further enflamed by them, there were in Turkey misgivings about US policy towards the region--including Turkey itself. There were widespread concerns that the US would support the establishment of a Kurdish state in the region, and then use it for its power politics objectives in the Middle East. Above all, Turkish public opinion had long been critical of the US for not ending the instability in Iraq during the 1990 s by peaceful means, and for giving an opportunity to the PKK terrorists to find shelter in northern Iraq. As a result of all of the above, Turkish public opinion has developed a negative image of the US. In a public poll conducted in Turkey in 2003 by the Pew research centre, 83 percent of Turks have a negative image of the US and 71 percent see the US as a military threat to Turkish security. ${ }^{14}$

In light of the lessons learned at the end of the Gulf War of 1990-91, both the Turkish public and the state were very cautious about becoming involved in another war in Iraq. It can be argued that Turkey acted according to the proverb 'once beaten twice shy.'

\section{Lack of Agreement on the Conditions of Cooperation}

After all, Turkey was concerned that it could face similar problems this time again since there was no clear and final agreement with the US. Negotiations had started long before the war did. During the negotiations, which took place in Ankara and Washington over two months, the sides focused on three areas (economic, military/security, and political), but could not come to a final agreement on all issues.

As we do not have the original records of the talks during the negotiations, it is hard to make scientifically proven conclusions.

${ }^{14}$ Radikal, 4 June 2003. 
However, certain conclusions based on analyses of media sources at that time provide suggestions for why the negotiations between Turkey and the US did not produce an agreement. ${ }^{15}$

The first point of disagreement between the two sides concerns financial matters. On that matter, Turkey asked guarantees for full compensation of its losses, which, according to news reports, amounted to $\$ 32$ billion in aid, and a written agreement for this compensation. But the US offered only $\$ 6$ billion as grant and up to $\$ 20$ billion as a loan to be approved by the Congress, and tied to IMF conditions. On the other hand, it was reported that Recep Tayyip Erdoğan, the leader of the AKP, also tied Turkey's support to written guarantees from the US. ${ }^{16}$

The second point of disagreement concerns military-security matters. On that front, Turkey wanted to send as many troops to Iraq as the number of US troops passing through Turkey. These Turkish troops needed to be deployed in appropriate areas so as to stop refugees from Iraq, to fight against PKK terrorist activities, and to prevent the establishment of a Kurdish state in the region. There was no information in the media about whether the US accepted these requests. The only information in the media was that Turkey and the US could not reach an agreement about the position of the Turkish troops in the case of their entry into Iraq, and about the ways to arm and disarm the Kurdish fighters called peshmergas.

The third point of disagreement concerns post-war reconstruction of Iraq. On that issue, Turkey asked to play a considerable role in the reconstruction of Iraq after the war. In line with this demand, Turkey wished to improve the conditions of the Turcomans in the power sharing in a future government of a united Iraq.

The US faced a dilemma in giving a positive reply, especially to the second and third demands, because of the obstacle presented by

\footnotetext{
${ }^{15}$ Author's review of Turkish daily newspapers at that period; and Murat Yetkin, Tezkere: Irak Krizinin Gerçek Öyküsü (İstanbul: Remzi Kitabevi, $2^{\text {nd }}$ edition, 2004), especially pp.120-173.

${ }^{16}$ Middle East International, No. 695, 7 March 2003, p. 9.
} 
the Kurdish factor. Kurdish groups, led by Barzani's KDP and Talabani's PUK did not want to have Turkish troops deployed in the north of Iraq, and they expressed their willingness to fight, if necessary, against the Turkish forces inside Iraq. They held demonstrations against Turkey, burning Turkish flags and photographs of Atatürk.

The US adhered to the Kurdish views for two reasons: Firstly, the US had commitments to the Kurds for ten years, and it knew it would need them in the future. Secondly, if the US accepted Turkish forces into northern Iraq, and refused the Kurds, there was a strong possibility of a civil war between the Kurds and the Turcomans, who would most likely be assisted by the Turkish troops. Such a civil war could derail the US war plans and have obvious negative effects on the US's military operation in Iraq. ${ }^{17}$ Thus the US Secretary of State was reported to have stated that, "We do not want to see anything happen that would precipitate a crisis between Turkey and the Kurdish population in northern Iraq'. ${ }^{18}$

Because of these differences in policies and demands on the eve of the voting in the TGNA, the two countries could not reach an agreement. By 1 March, although there were positive signals, an agreement had not been signed yet because the sides could not agree on all points. This failure was admitted to by Recep Tayyip Erdoğan just before the AKP's Party Group meeting in the TGNA on 25 February. The parliamentarians were not simply dissatisfied with this outcome, they were furious. Indeed, they were upset due to the US's failure to persuade the Kurds of Iraq to accept the deployment of Turkish troops in Iraq during the war. ${ }^{19}$

Fikret Bila, columnist in the Turkish newspaper Milliyet, argued that at the end of the negotiations Turkey and the US had agreed to sign a Memorandum of Understanding whose text was published in Milliyet. If the TGNA had endorsed the motion,

\footnotetext{
${ }^{17}$ Yola Habif, 'The Future of Iraq,' Turkish Policy Quarterly, Vol. 1, No. 4 (Winter 2002), pp. 101-111.

${ }^{18}$ Midddle East International, No. 696, 21 March 2004, p. 14.

${ }^{19}$ Yetkin, Tezkere: Irak Krizinin Gerçek Öyküsü, pp. 165, 172, 173; interview with some AKP Parliamentarians.
} 
according to Bila, Turkey and the US would have cooperated during the war, and the Turkish troops would have been deployed into the Kurdish-populated area of northern Iraq. ${ }^{20}$

Both Bila's views and the published text are disputable for two reasons. Firstly, the published text cannot be accepted as an original document because it did not contain the signatures. Nor is it an agreement in the formal sense because the Memorandum of Understanding is a 'written statement that is prepared specifically for a person or committee in order to give them information about a particular patter, i.e. report' ${ }^{21}$ Secondly, the view that Turkish troops would have been deployed in northern Iraq if the motion had passed, cannot be justified by the developments during and after the war. The post-war developments show that the US has been very reluctant to let the Turkish troops enter into northern Iraq, so as not to see conflict break out between the Turkish army and the Iraqi Kurds.

Consequently, due to the above problems, Turkey did not take part in the Iraq war. Turkey's only support to the US military operation was the opening of Turkish airspace for the overflight of US warplanes to Iraq during the war. At the end of regular warfare operations, the US had toppled the Saddam regime, leading to several consequences for Turkey and Turkish foreign policy.

\section{Consequences of the Out-of-War Position for Turkey}

Turkey's out-of-war position and the ensuing conditions in Iraq following regular combat have produced both positive and negative consequences for Turkey. From one perspective, Turkey's out-of-war position had some positive results for Turkey politically, legally, morally, economically and in terms of security, because it prevented various problems that Turkey might have otherwise faced. These positive results were related with Turkey's domestic and foreign policies in both the short and long terms.

${ }^{20}$ Milliyet, 22-26 September 2003.

${ }^{21}$ Collins Cobuild English Language Dictionary (London: HarperCollins Publishers, 1987), p. 906. 


\section{Positive Consequences}

- Saving itself from a (Civil) War in Iraq

By staying outside of the Iraq war, Turkey saved itself from plunging into a war in Iraq, and from the negative consequences of becoming embroiled in such a war. How could have this happened?

Although speculative and hypothetical, a number of scenarios that could have emerged had Turkey entered Iraq-regardless of its positive and humanistic intentions and plans-can be envisioned. First of all, there is no doubt that if Turkey had sent troops to Iraq, Turkey would have certainly been plunged into chaos and trouble in Iraq, just as the US and its allies have been since the end of the US military operation in May 2003. Turkey could have seen resistance firstly and mostly from the Kurdish groups in the north, but also from those fighting against the occupying soldiers in the centre and south of Iraq. Worse, Turkey's participation in the Iraq war would have drawn negative reactions from other Iraqi neighbors, mainly Iran and Syria. These countries would likely have misinterpreted Turkey's participation as a quest for control and hegemony over northern Iraq-a potential spark for a balance of power war among the three countries. In such an event, we could have seen a widespread regional war among these countries, with the possible participation of others in support of these fighting countries. All of this would have cost high human, economic and political losses, just like Iran and Iraq paid during the Iran and Iraq war in the 1980s, and Turkey paid in its fight against the PKK during the 1990s.

In the view of these probabilities, it can be safely argued that Turkey saved itself from such dangers during and after the war in Iraq. Indeed, this has also had a positive effect on Turkish economic, political and social situations.

- Saving itself from a Set of Potential Crises in the Domestic Arena

Turkish economic, social and political systems have not been affected very much by Turkey's out-of-war position. Economically speaking, Turkey did not face a big and insurmountable economic crisis. Foreign currency instability lasted a very short time. As Turkey 
did not have military costs, Turkey's budget was not greatly affected. Nor was Turkish tourism harmed because of the Iraq war.

Politically speaking, the democratic process proved its effectiveness, reflecting the influence of legislative power on Turkish foreign policy making. There has been a greater sympathy for Turkish democracy in the world, contributing, though indirectly, to Turkey's quest for full membership in the EU as well. Moreover, if the resolution had passed, there was a strong possibility of a government crisis in Turkey, as some AKP parliamentarians and ministers were likely to have left the Party.

Finally, social stability did not break down as a result. Turkish pressure groups, especially those radical and anti-war groups including the Kurds and the leftists in Turkey, did not have disturbing or uncontrollable public demonstrations and revolts. Turkish public opinion did protest against the US operations, but it did not go so far as to create chaos.

\section{- Improving its Image in Most of the World}

On the contrary, Turkey's prestige and image in world politics can be said to have been boosted. Turkey's refusal to support what is widely viewed as the US's illegitimate operation in Iraq was seen as a right and proper policy in most of the world public opinion. Turkey's image in Europe and in the Arab and Islamic world in particular has risen as a result of the 'no' vote. Turkey is seen as a country where there is a strong democratic process. Although there are of course some who criticized Turkey for failing to support the US, most observers admired this stance.

Indeed, since then there have been rather encouraging developments in the Turkish democratic process. Subsequent to the vote, the AKP government took important and even radical steps in domestic politics and foreign policy so as to improve democratic standards. In domestic politics, there have been made a number of reforms such as amendments in the Turkish constitution so as to increase political, social and cultural freedoms, and to reduce the influence of the non-civil organs, such as the National Security Council, over the government and parliament. As a result of passing these reforms, Turkey came to complete the Copenhagen criteria for 
full membership in the EU. In this regard, it must also be noted that the AKP government played a very radical role for the resolution of the Cyprus problem according to UN Secretary General Kofi Annan's plan. Here, the government achieved a great change of mind and perspective in the Turkish state tradition by trying to change the status quo on the island.

\section{- Rapprochement between Turkey and the EU}

Indeed, most of these developments were carried out for advancing Turkey's steps toward full membership in the EU. This was not a big surprise because there has been an increasing rapprochement between Turkey and the EU after the Iraq war--one of the important positive outcomes of the Iraq war.

There have been substantial changes in the perspectives of Turkey and the EU toward each other. Most importantly, both Turkey and the EU (in particular Germany and France) have realized that their security perspectives are closer than ever before. No doubt this perception has had a positive effect on Turkey's prospects for full EU membership, which depends not only on the implementation of reforms on issues of 'low politics' (such as the harmonization of Turkish laws with EU standards in democracy, human rights, and the legal, economic and political systems), but also on having common positions on 'high politics' issues. The EU now realizes that its security is closely dependent on Turkey's foreign security and political behaviour. It has begun to view Turkey not as a 'security consumer country' as before, but as a 'security provider country'. On the other hand, Turkey now realizes that in order to achieve peace, stability and security in its surrounding region, it should take the EU factor into consideration.

Most high level EU officials, such as former Head of the Commission Romano Prodi, High Commissioner Javier Solana, former Commissioner for Enlargement Günter Verheugen, as well as German Chancellor Gerhard Schroeder, German Foreign Minister Joschka Fischer and French President Jacques Chirac, have made very important statements in favor of Turkey's membership in the EU since the end of the war. The most crucial point of their statements is the fact that they now see Turkey-EU relations more from a strategic and security point of view, than from a so-called 'low politics' 
perspective. ${ }^{22}$ It is nonetheless important to bear in mind that Turkey's membership in the EU will be achieved not only by the attainment of common strategic visions, but also by the completion of the Copenhagen Criteria in domestic politics.

\section{Negative Consequences}

From another perspective, Turkey's out-of-war position had some negative outcomes for Turkey and Turkish foreign policy. The most important of them was the outbreak of a serious crisis in Turkish-American relations during and after the war.

\section{- Crisis of Confidence in Turkish-US Relations}

The US Administration was shocked at not having received Turkey's support and cooperation because it was a surprising diversion from the traditional patterns of cooperation between the two countries in the post-Cold War era. On the other hand, Turkey was disappointed by the US policy towards Turkey during and after the Iraq war. Since the 1 March voting, the alliance cohesion between Turkey and the US has been damaged by a series of shockwaves, leading to the deepening of the crisis, which has been described as a 'malaise' in Turkish-American relations at the bilateral level. ${ }^{23}$

The nature of the crisis can be analyzed from three angles: The first and the main element of the crisis between Turkey and the US is increasing mistrust towards each other. The 1 March voting seriously damaged both countries' strategic thinking, which had developed over the last fifty years, and especially since the end of the Cold War. The two countries had developed intimate relations within NATO and bilateral contexts for the attainment of common values such as democracy, liberalism, the rule of law, and the spread of the same values to other parts of world. This understanding was now eroded by

${ }^{22}$ For these statements, see Şahin Alpay, 'AB: Evet ile Hayır Arasında', Zaman, 20 January 2004; Zaman, 30 April 2004.

${ }^{23}$ Hichem Karoui, 'Turkey-US: A Misunderstanding or a Malaise?' www.amin.org/hichem_karoui/nov07.html. 
the growing rift not only on the nature of democracy in Turkey but also on the developments in Iraq.

A statement made by US Deputy Secretary of Defense Paul Wolfowitz to Turkish journalists from CNN Turk generated shock and disappointment in Turkey. Wolfowitz harshly criticized the Turkish Generals for displaying 'inaction' in the passage of the government motion, and for not showing the determination that the US expected from them. He bluntly blamed the Turkish army for not doing enough to influence the outcome of the Parliament vote.

Moreover, Wolfowitz tied the restoration of good relations between Turkey and the US to an apology to be made by Turkey, when he said, '...Let's have a Turkey that steps up and says, 'we made a mistake, we should have known how bad things were in Iraq, but we know now. Let's figure out how we can be as helpful as possible to the Americans". ${ }^{24}$ Such remarks further deepened the crisis of confidence because of a strong negative reaction from Turkish public opinion. Wolfwitz's remark was seen as displaying a lack of respect to the Turkish Parliament's discretion as well as to democratic standards in Turkey.

A Wolfowitzian understanding of democracy was not shared by Turkish officials. Turkish Prime Minister Erdoğan replied that 'Turkey, from the beginning, made no mistakes and took all the necessary steps in all sincerity.' General Büyükanıt said that 'The Turkish Armed Forces always carry out their duties in a democratic way'. 25

The crisis broadened over the following months, as new sources of disagreements and problems emerged in Iraq. In other words, as the second angle of the crisis, there emerged such problems as the revealing of mounting clashing interests and understandings between the two countries over the reconstruction and future of Iraq. Indeed, the main and real consequence of the Iraqi war on TurkishAmerican relations is related with the question of whether and to

${ }^{24}$ American administration to punish Turkey over Iraq, 7 May 2003, www.english.pravda.ru/world/20/91/366/9922_Turkey.html.

${ }^{25}$ Middle East International, No. 700, 16 May 2003, p. 24. 
what extent Turkey and the US are to cooperate over Iraq's reconstruction.

The developments since the beginning of the Iraq war show that Turkey and the US have diverging interests and concerns about Iraq. The main source of the disagreement and the crisis is centered on the position of the Kurds in Iraq. Since the Gulf War of 19901991, US policy towards Iraq is mainly based on the support coming from the Kurdish groups. The Iraqi Kurds came to be US's 'staunchest ally' in the region at the detriment of Turkey's position. This favor was emboldened especially since the Iraqi war, where the US preferred the Kurdish role and position in Iraq to Turkey's role and contribution. This is the heart of the problem in the growing USTurkish crisis.

While relying on the Kurds in the reconstruction of Iraq, the US aimed to exclude Turkey from Iraq militarily. It was argued that after the war the Kurds became the main building block of the US policy toward Iraq. It could be considered a 'Kurds-first policy'. ${ }^{26} \mathrm{On}$ the other hand, the Kurds cooperated with the US in order to have greater influence during and after the war. Kurdish leader Jalal Talabani stated in an interview on CNN on 2 May 2004 that Kurds have seen the US as a liberator and the best friend.

There are three reasons behind the US's 'Kurds-first' policy: Firstly, the US still fears a civil war between the Kurds and Turks inside Iraq, and the potential resulting collapse of the entire US policy towards Iraq. Secondly, the Kurds, arguing that they can best serve US interests in the reconstruction of Iraq, have convinced the US administration not to allow Turkey to play a military role in Iraq. Thirdly, because both the US and the Kurds suspect that Turkey might have a sphere of influence in Iraq, Turkey is not permitted to have a say over the reconstruction of Iraq. There have been several developments after the war to prove the above argument.

One of them was the capture of 11 Turkish soldiers by the US marines in Suleymaniyah on 4 July 2003. Kurdish leaders motivated

${ }^{26}$ M. Hakan Yavuz, 'Provincial/Not Ethnic Federalism in Iraq', Middle East Policy, Vol. 11, No. 1 (Spring 2004). 
the American troops to conduct the operation against Turkish Special Forces in Suleymaniyah, due to 'suspicions of plotting against a senior political figure in Kirkuk'. The result was a rather blunt and rude capture and detainment of 11 Turkish soldiers and 13 civilians by some 100 members of the US $173^{\text {rd }}$ Airborne Brigade. ${ }^{27}$

The incident created much tension between the two countries. The Turkish Chief of Staff described it as 'the greatest crisis of confidence between the armed forces of the two countries', although he did not believe it to be a Washington or US Army policy. ${ }^{28}$ Despite the softening messages from Turkish authorities, it caused serious damage to the alliance between the countries for three reasons:

Firstly, it was another big blow to the Turkish-US cooperation over Iraq continuing since the 1990-1991 Gulf war. Indeed, as part of the Operation Provide Comfort process, Turkish soldiers had been deployed in the region for about a decade, in order to observe the security developments in the region. Moreover, they were in northern Iraq with the acknowledgement of the US officials in the sense of security cooperation over Iraq. Secondly, Turkish authorities were not convinced with the allegations that the Turkish troops were planning a plot against a Kurdish leader in Kirkuk. If there was such a case, the US officials in the region could have informed the Turkish authorities in Ankara to take necessary steps and deal with it. In addition, the mode of capture, i.e. breaking in the doors of their office, unceremoniously handcuffing the Turkish soldiers, putting bags over their heads and taking them to Baghdad without informing the Turkish government, was very disgraceful for the Turkish Armed Forces. Thirdly, and most importantly, the US Armed Forces were misled by unconfirmed and false information given by the Kurdish groups in the region. It was an indication of US mistrust in the Turkish Armed forces, and the US preference of the Iraqi Kurds to the Turks.

\footnotetext{
${ }^{27}$ For example, Milliyet, 5 July 2003; Middle East International, No. 704, 11 July 2003, p. 14.

${ }^{28}$ Baku Today Net, 9 July 2003, www.bakutoday.net/view.
} 
After the incident, in an agreement with the US, Turkey gradually withdrew its troops in small numbers, from northern Iraq, with the single condition that Turkey will have some liaison officers in Iraq for communication with the US officers in Iraq, and that the US will eliminate the PKK-KADEK from northern Iraq, prevent the establishment of a Kurdish state, and exclude anti-Turkish individuals in the formation of the Permanent Governing Council of Iraq. ${ }^{29}$ Turkish Foreign Minister Gül stated, 'as long as there is stability and security for Turkey, there was no need for Turkish troops inside Iraq...[because] Turkey, as a country always advocating Iraq's territorial integrity, never wants to have a military presence in the territory of another state'. 30

Another important development showing the US's preference for the Iraqi Kurds occurred later on. In the face of rising insecurity in Iraq, the US admitted that it would like Turkish contribution. The Turkish government yet again put its neck on the line and asked for a mandate from the TGNA to send Turkish troops down through the north of Iraq to serve as peacemaking forces to help restore stability in central Iraq. Despite public opposition in Turkey, the TGNA gave this mandate to the Erdoğan government on 7 October 2003. Indeed, the decision was made to assist the US to establish security and peace in Iraq. This move could also be seen as a Turkish effort to mend the bridges with the US. As reported in the media, the US was to extend $\$ 8.5$ billion credit to Turkey, on the condition that Turkish troops not be deployed in northern Iraq, but only in the war-torn area around Baghdad. ${ }^{31}$

Turkey was again unable to send its troops to Iraq due to the opposition stemming mainly from the Kurdish members of the Iraqi Governing Council, who feared that their northern neighbors would try to grab territory and influence Iraqi politics. A Council member stated that 'We believe any interference from a neighboring

\footnotetext{
${ }^{29}$ Sabah, 18 July 2003.

${ }^{30}$ Hürriyet, 18 July 2003.

${ }^{31}$ This was at the top of the agenda in Turkish politics and Turkish media during early October 2003. Yetkin, Tezkere: Irak Krizinin Gerçek Öyküsü, pp. 201-207. Turkish daily newspapers Hürriyet, Milliyet, Radikal, Zaman, Yeni Safak and others.
} 
country.... is unacceptable'. ${ }^{32}$ It can be argued that in the view of the fact that the Kurds have had the upper-hand in the Governing Council, Turkey's sending of troops was also prevented by the Kurdish groups as before. Not only the Kurds but also most Arabs were against Turkey's deployment of forces in Iraq to support US policy. As a result, after one month of futile negotiations with the US to proceed, the Turkish Government declared on 7 November that Turkey would not send troops to Iraq. Thus, the idea was finally dropped as Turkey and the US agreed that Turkish troops would not be deployed in Iraq under the given conditions. ${ }^{33}$

Turkey was also concerned about the Kurds' role in the reconstruction of Iraq in accordance with the Interim Constitution of Iraq, signed on 8 March 2004. Articles 53 and 54 make special reference to the Kurdish Regional Government and its Competences, making them a distinctive member of the Iraqi federation--to the detriment of other Iraqis such as the Shi'as and the Turcomans. ${ }^{34}$

This was a disturbing development not only for the Shi'as but also for Turkey. Turkey believes that there should be a fair power sharing and division of labour in the Governing Council, and in the drawing up of the Iraqi Constitution. In particular, Turkey argues that the federalism of Iraq must not be based on 'ethnic criteria', but on 'geographic criteria'; the Turcomans must have fair share, while the Kurds must not have so much power and rights so as to lead to the establishment of a Kurdish state. Despite Turkey's suggestions, the Kurds ultimately did gain the 'lion's share', whereas the Turcomans were not given what Turkey expected, neither in the Council nor in the Interim Constitution.

Related to the distribution of power and rights between the Kurds and the Turcomans is the status of the oil-rich Kirkuk and Mosul regions. Turkey believes that the economic wealth of these regions must be used for the benefit of all groups in Iraq, and that

${ }^{32}$ USA Today, www.usatoday.com/new/world/2003-10-07-turkey-us_htm.

${ }^{33}$ Yetkin, Tezkere: Irak Krizinin Gerçek Öyküsü, pp. 225-265.

${ }^{34}$ The Iraqi Interim Constitution, officially titled as 'Law of Administration for the State of Iraq for the Transitional Period' (8 March 2004), www.oefre.unibe.ch/law/icl/iz00000_html. 
these cities' ethnic compositions must not be changed artificially by moving Kurds in. Thus, Turkey defined and declared some 'red lines' concerning the position of the Kurds as well as of the strategic regions.

When the Kurds crossed over the 'red lines' by entering Kirkuk and Mosul for the purpose of making changes in the ethnic and administrative composition of these two cities, Turkish Armed Forces were put on alert to interfere into the region. Again, the US opposed the Turkish incursion, and warned Turkey not to enter Iraq unilaterally. US Envoy Zalmay Khalilzad bluntly said during his visit to Ankara on 14 March that: 'Unilateral Turkish intervention in northern Iraq would be a 'tragedy' for US-Turkish relations' ${ }^{35}$ After intensive diplomatic initiatives by the Turkish Government, the US soldiers took control of the situation and prevented the Kurdish control of the two cities. They were unable however, to prevent the mass migration and settlement of Kurds.

Finally, Turkey is concerned about the presence of the PKK terrorists in northern Iraq, and expects their elimination from the region. However, despite the US assurances to do so, PKK elements are still based in the northern part of Iraq.

Do all these factors mean that Turkey has lost all its importance and role over Iraq? It seems so as far as Turkey's military and political roles are concerned. So long as the US and the Kurds act in cooperation for the reconstruction of Iraq, Turkey is unlikely to have any military or political involvement in northern, or other parts of, Iraq such as that which it had in the 1990s and even in the 1980s under the hot-pursuit agreement between the two countries. Consequently, since the US has occupied and gained a dominant position in the reconstruction of Iraq, Turkey has lost its influence over the formation of a new Iraq.

However, as Turkish Foreign Minister and Deputy Prime Minister Gül clearly expressed in a talk given at the Washington

${ }^{35}$ Quoted in Middle East International, No. 596, 21 March 2003, p. 14. 
Institute for Near East Policy, ${ }^{36}$ Turkey aims to develop relations with Iraq in order to establish peace and security in the country. Turkey wants to have a role and position in the economic, infrastructural and social reconstruction of Iraq. There have been some attempts for Turkey's involvement in this respect. Turkish and Iraqi businessmen and officials have exchanged visits to cooperate and do business in Iraq. Turkish businessmen are now constructing hospitals, schools, and bridges, as well as exporting medicine, food, construction material, and so on. While all these activities are encouraging, they can hardly be sustainable and effective in the short- and mid-terms simply because of continuing chaos and anarchy in Iraq. This pessimism can be proved by the murder of a number of Turkish lorry drivers inside Iraq in 2004.

Based on the crisis of confidence that has existed since the Iraqi war, the macro question, being the third angle, is whether this crisis may also lead to a deeper and strategic change in TurkishAmerican relations, or whether it will remain as a temporary disagreement between the two countries. Some believe that the Iraqi case displayed that the idea of a new security cooperation between Turkey and the US, brought up in the aftermath of the September 11, is likely to contain serious problems and risks for Turkey. The case also showed that the two countries' strategic interests in the Middle East and Central Asia do not always correspond. ${ }^{37}$ Thus, what the former US President Clinton had described in his speech in the TGNA in 1999 as a 'strategic partnership' between the two countries, has basically come to end. This means that the two countries do not have common interests and policies regarding the developments in the region. In particular, Turkey and the US do not have similar perceptions of security and change in the region. For example, they do not have consistent positions towards the future of Iraq, Iran, Syria and others in the region. As Morton Abramowitz, former US Ambassador to Ankara said, 'it might sound hyperbolic but it feels

${ }^{36}$ Washington D.C. (25 July 2003), NTV and CNN Turk televisions, 20.0020.30 .

37İhsan D. Dağı, 'Limits of Turkey's 'Strategic Partnership with the USA: Issues of Iraq, Democratisation and the EU', www.tusiad.us/specific_page.cmf?CONTENT_ID:243. 
like ten years of improving relations have just gone down the drain' ${ }^{38}$

Others, however, believe that Washington's strategic support for the Kurds is a short-term interest. The US's strategic support for Turkey, on the other hand, is a long-term interest since Turkey straddles Europe, the Caucasus, Central Asia, and the Middle East. Consequently, they argue, Washington will not swap its relations with Ankara, a long-time US strategic ally, for Kurdish aspirations of statehood. ${ }^{39}$

There is no doubt that the developments since the end of the Cold War, the September 11, and the Iraq debacle have had a big impact on Turkey's strategic thinking. These events in world politics have influenced three characteristic parameters of Turkey's security culture. Since there is no clearly unified West today; Turkey's geopolitical and geostrategic importance is questioned; and the statecentric and military methods are no longer valid for achieving security. ${ }^{40}$

But especially in the view of the Iraq experience, there will be some substantial changes in the strategic perspective of TurkishAmerican relations, leading to some structural changes in the long run. The extent of all these changes will depend, however, on the development of three processes: US policy toward the Iraqi and the Kurdish question; the future of Turkey's relations with the EU; and the developments in Turkish politics, i.e. the presence of the Justice and Development Party as believers in soft politics and EU membership. Supposing that the reconstruction of Iraq is based on US's Kurds-first policy at the expense of Turkey's interests and policy, that Turkey starts negotiations with the EU for full membership, and that the AKP government manages to enhance democratization and civil ruling in Turkish politics, Turkey-US

${ }^{38}$ Views on Turkey-US relations, Council on Foreign Affairs, www.cfr.org/background/background_iraq.php.

${ }^{39}$ Eric Marquardt, 'Turkey: Back on Side with the United States', www.thepalmerpress.com/rieas $18 . \mathrm{htm}$.

${ }^{40}$ H.Tarık Oğuzlu, 'Changing Dynamics of Turkey's US and EU Relations', Middle East Policy, Vol. 11, No. 1 (Spring 2004), p. 104. 
strategic relations will further decline. As a result, Turkey would be unlikely to want to play a hard-politics/military-oriented role in the so-called Eurasia, as was the case in the 1990s. Although Turkey would maintain its membership in NATO, it would hesitate to act as NATO's far-front post in the case of military operations especially if there is a division between the so-called Europeanists and Atlanticisits within NATO. So, for example, if the recently emerging US policy of a 'Greater Middle East' is to make Iraq-like operations and 'solutions' in the region, under the current circumstances, Turkey would not participate in them.

However, provided that Turkey resolves its domestic political and economic problems, and improves its EU membership process, Turkey's role in the Greater Middle East Initiative would be to help the regional countries have reforms in the political and economic systems if they wish so. Then, Turkey could play a positive role in a US policy of nation building in the Middle East and the fight against global terror. ${ }^{41}$

Such a development would mean that Turkey changes its strategic thinking and policy towards Eurasia from a US-style of change to an EU-style of change. In other words, Turkey would follow the EU's 'soft security (society) model', rather than the US's 'hard security (state) model'. Namely, security, stability and peace in the chaotic countries would be seen as attainable not by increasing military capabilities and operations and resorting to war, but by solving the underlying and deeper problems in those countries by using economic, social, political and diplomatic instruments.

\section{Conclusion}

The Iraqi war was an important test case not only for Turkey and Turkish foreign policy, but also for regional dynamics and for US foreign policy. Aside from its unjust causes, the war generated unhappy consequences for the Iraqi people and for US security and foreign policy. Indeed, the developments after the war show that the US operation did not bring an order and stability into the country

\footnotetext{
${ }^{41}$ Ibid. p. 100.
} 
since the US did not take into account Iraq's and region's dynamics. The US is not therefore equipped to cope with the historical, cultural, and political challenges of the region. It seems that the US underestimated the challenge of nation building after destroying them. As a Turkish proverb says, "it was easy to destroy, but it is now very difficult to re-build'.

Iraq has plunged into chaos, anarchy and instability since the war. There has been a growing security dilemma for the US and other occupying countries in Iraq. Almost every day, US soldiers, foreign journalists and the man-in-the-street are being killed; UN headquarters and foreign embassy buildings have been destroyed. The US has lost more troops since the official end of the war than during the military operation in Iraq. Moreover, the appalling human rights violations and the abuse and maltreatment of prisoners in the Abu Gharib prison by the US guards have further deteriorated the record of US policy in Iraq.

Turkey's out-of-war position has been a rather fortunate and positive case for its own interests. Despite some shortsighted criticisms of the TGNA's 1 March decision, most now admit that Turkey has gained more by having remained out of the war than it would have attained by becoming involved in the war.

Turkey now needs to realize that her long-time ally, the US, has divergent foreign policy interests in Iraq and around the region, most of which do not necessarily comply with Turkey's national interests. Turkey must therefore develop alternative engagements with the regional and global powers, despite some opposition from US decision-makers regarding Turkey's close relations with Syria and Iran. ${ }^{42}$

Turkey's search for its own national interests may still be consistent with those of the US. As long-term allies during the Cold War and the 1990s, Turkey and the US may still cooperate for peace, stability and security in the region. But it seems that such cooperation

\footnotetext{
${ }^{42}$ Richard Perle is reported to have said that 'the resumption of close ties between Ankara and Washington would be conditional on Turkey adopting a policy similar to that of the Bush Administration against Syria and Iran'. Middle East International, No. 700, 16 May 2004, p. 24.
} 
will not be based on the Cold War methods and logic, but on novel strategies and policies. As Robert Pearson, former US Ambassador to Turkey, argued '[they] have always been allies, in the future [they] will continue to be allies. Relations between the two countries will be rebuilt on a new page'. ${ }^{43}$ For such a rebuilding, both Turkey and the US should re-examine the wrongs of the past so as not to repeat them in the future. They must also come to see each other in the context of the changing dynamics of regional and global politics, including the case of the EU integration process and its effects on the surrounding regions.

${ }^{43}$ Baku Today Net, 9 July 2003. www.bakutoday.net/view.php? $d=5303$. 